\title{
GAS GENERATION FROM HANFORD GROUT SAMPLES
}

\author{
C. D. Jonah, S. Kapoor, M. S. Matheson, W. A. Mulac, and D. Meisel
}

Chemistry Division, Argonne National Laboratory

\section{ECEIVEO}

FFB 281996

OSTI

In an extension of our work on the radiolytic processes that occur in the waste tanks at the Hanford site, we studied the gas generation from grout samples that contained nuclear waste simulants. Grout is one option for the long-term storage of low-level nuclear waste solutions but the radiolytic effects on grout have not been thoroughly defined. In particular, the generation of potentially flammable and hazardous gases required quantification. A research team at Argonne examined this issue and found that the total amount of gases that were generated radiolytically from the WHC samples was an order of magnitude higher than had been predicted. The observations imply that novel pathways for charge migration from the solid grout to the associated water are responsible for gas evolution. The grout samples produced hydrogen, nitrous oxide, and carbon monoxide as well as nitrogen and oxygen. Yields of each of these substances were determined for doses that are equivalent to about 80 years storage of the grout. Carbon monoxide, which was produced in $2 \%$ yield, is of particular importance because even small amounts may adversely affect catalytic conversion instrumentation that has been planned for installation in the storage vaults.

These studies were supported by WHC. The expertise, the knowledge, and the instrumentation that Argonne exploited in this study were developed during many years of support by the Division of Chemical Sciences, Basic Energy Sciences.

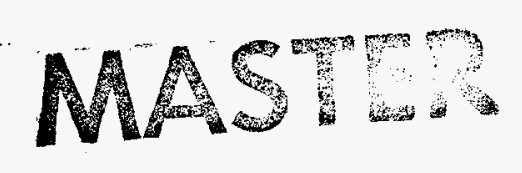




\section{DISCLAMMER}

Portions of this document may be illegible in electronic image products. Images are produced from the best available original document. 


\title{
GAS GENERATION FROM HANFORD GROUT SAMPLES
}

\author{
C. D. Jonah, S. Kapoor, M. S. Matheson, W. A. Mulac, and D. Meisel \\ Chemistry Division, Argonne National Laboratory
}

Some low-level radioactive liquid wastes from the tanks at Hanford might be mixed with cement and other solids for long term storage as grout. Consequently, it is important to determine the rate of radiolytic and thermal production of gases in this grout. In addition to the obvious issues of safety involved in the gas generation in general, in this particular case the rate of release of the gases relative to the rate of its generation is also important because accumulation of gases in the solid may lead to its cracking, leaching and a variety of other adverse effects. The same task force at CHM/ANL that studied gas generation from the tanks' waste simulants in the past, was requested to measure the yields of gases from the grouted waste simulants as well.

The radiolytic and chemical rates of the following gases were measured: $\mathrm{H}_{2}, \mathrm{~N}_{2}, \mathrm{O}_{2}, \mathrm{CO}$, $\mathrm{CH}_{4}$, and $\mathrm{N}_{2} \mathrm{O}$ at several dose rates and up to $100 \mathrm{Mrad}$, a dose equivalent to more than 80 years storage of typical grouted waste. After this period of time, the dose rate would have decayed to about $15 \%$ its initial value. Two batches of WHC-supplied samples of grouted simulated waste have been $\gamma$-irradiated for these studies. The first batch included waste simulant that represents the feed solution that was temporarily stored in the tanks. For the second batch, the same simulant was preirradiated to $35 \mathrm{Mrad}$ prior to incorporation into the grout and therefore it simulates waste that was stored in the tanks for approximately a decade prior to grouting. Figure 1 compares the yields of $\mathrm{H}_{2}$ generated from these two batches of samples. Similar experiments were conducted to determine the yields of the other gases and the results from these experiments are summarized in Table 1. Whereas there are differences in yields of individual gases between the two batches, the sum of the yields of all gases is similar in both. 
Two other types of experiments were conducted in order to ensure that all the gases that are released by the irradiated grout are accounted for in the gas chromatographic experiments described above. In the first, the total pressure that is generated by the grout has been measured and was compared to the sum of the gases that were determined separately and are given in Table 1 . The very good agreement between these two measurements is shown in Figure 2. In another set of experiments a mass-spectrometric analysis was conducted on the mixture of gases and revealed only trace amounts of $\mathrm{H}_{2} \mathrm{~S}$ and $\mathrm{NH}_{3}$ in addition to the gases already discussed. We conclude that the gases given in Table 1 constitute the bulk of the mixture.

The decrease in $\mathrm{H}_{2}$ and $\mathrm{N}_{2}$ yields, and the increase in $\mathrm{O}_{2}$ yields following preirradiation can be rationalized based on the assumption, experimentally verified elsewhere, that the concentration of organic solutes has decreased, and nitrite increased, upon the preirradiation. Organic compounds contribute to $\mathrm{H}_{2}$ generation, they are required for the production of $\mathrm{N}_{2}+\mathrm{N}_{2} \mathrm{O}$ and they inhibit $\mathrm{O}_{2}$ production. Most surprising is the high total yield of gases and the high yield of $\mathrm{H}_{2}$. Model calculations show that if the radiation energy that is absorbed in the solid does not escape to encounter $\mathrm{H}$-containing chemicals (water or organics), $\mathrm{H}_{2}$ yields should have been much smaller. To obtain the high yields observed one needs to assume escape of charge carriers from the solid to the aqueous phase and/or low nitrate and nitrite concentrations in the aqueous phase. If reduction of $\mathrm{H}_{2}$ yields is desired, we recommend increasing the concentration of these two scavengers, provided it does not adversely affect other properties of the grout.

Special effort was invested in the determination of $\mathrm{CO}$ yields because of its adverse effects on catalytic converters. An induction period in the production of $\mathrm{CO}$, and an actual decrease in yield above about $60 \mathrm{Mrad}$ for the preirradiated samples suggest that $\mathrm{CO}$ is a secondary radiolytic product, and that $\mathrm{CO}$ eventually is also destroyed radiolytically.

Thermal rates of gas generation were also measured in the range $24-90^{\circ} \mathrm{C}$ since the temperature of the grout may be higher than the ambient. Only at $90^{\circ} \mathrm{C}$ were small amounts of gases generated although outgassing of trapped gases occurs at all temperatures studied. 


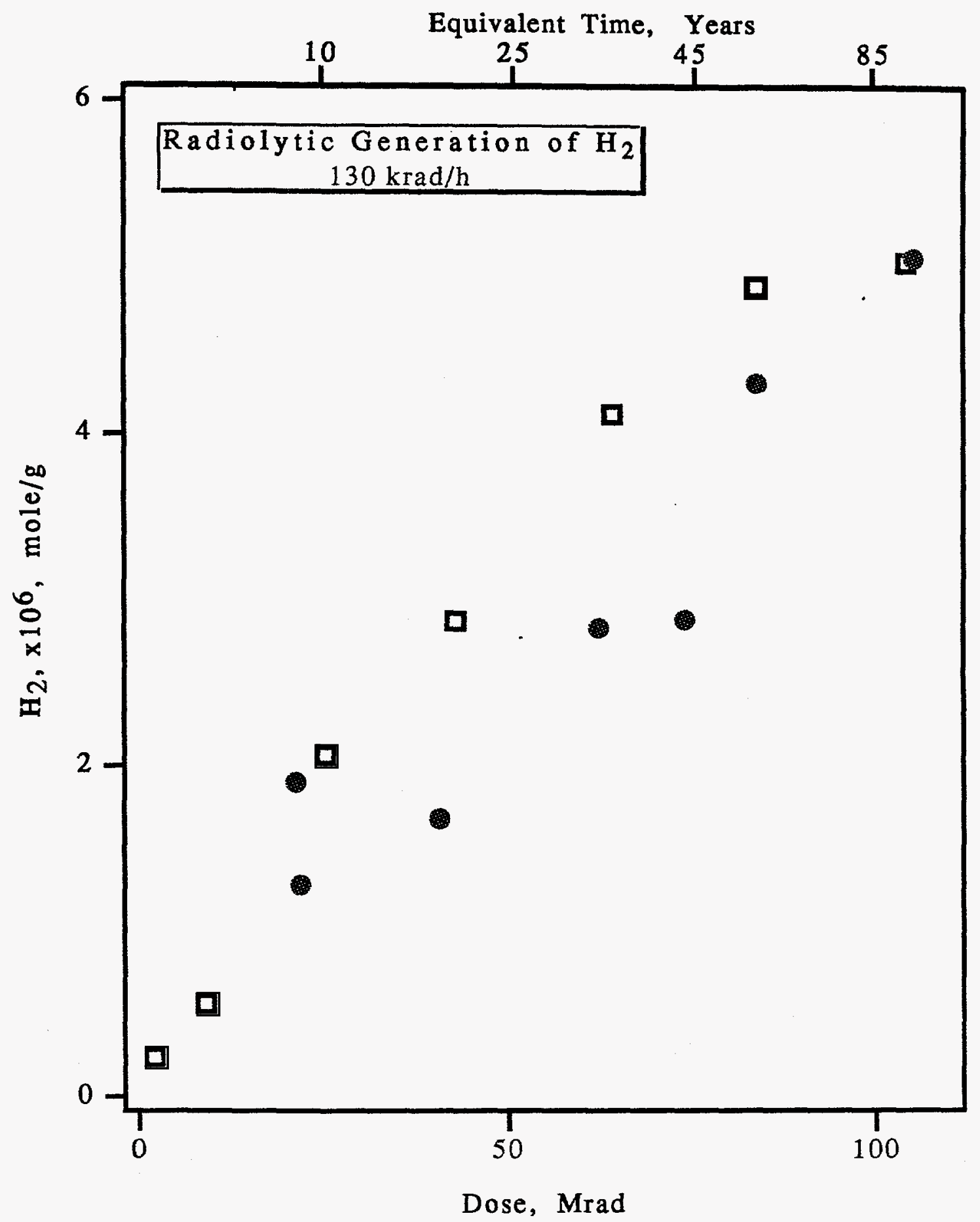

Figure 1. Generation of $\mathrm{H}_{2}$ from grout samples following irradiation at $130 \mathrm{krad} / \mathrm{h}$. Squares are non-preirradiated samples and circles are preirradiated samples. Top scale is "Equivalent Grout Time" calculated assuming initial dose rate in the waste of $0.3 \mathrm{krad} / \mathrm{h}$ and half-life of 30 years. 
Table 1: Yields of gases generated by radiolysis of the grout samples. All were irradiated at 130 $\mathrm{krad} / \mathrm{h}$ to a total dose of $100 \mathrm{Mrad}$. Yields were determined from slopes as in Figure 1.

\begin{tabular}{c|cc|} 
& $\begin{array}{c}\text { Non-Preirrad. } \\
\text { Samples }\end{array}$ & $\begin{array}{c}\text { Preirrad. } \\
\text { Samples }\end{array}$ \\
\hline Gas & $\begin{array}{c}\mathrm{G} \\
\left(\frac{\text { molecules }}{100 \mathrm{eV}}\right)\end{array}$ & $\begin{array}{c}\mathrm{G} \\
\left(\frac{\text { molecules }}{100 \mathrm{eV}}\right)\end{array}$ \\
\hline $\mathrm{H}_{2}$ & 0.056 & 0.041 \\
\hline $\mathrm{N}_{2}$ & 0.12 & 0.058 \\
\hline $\mathrm{O}_{2}$ & 0.026 & 0.078 \\
\hline $\mathrm{N}_{2} \mathrm{O}$ & 0.011 & 0.010 \\
\hline $\mathrm{CO}$ & 0.0042 & $\leq 0.0028$ \\
\hline $\mathrm{CH}_{4}$ & $\mathrm{G}\left(\mathrm{CH}_{4}\right) \leq 1 \times 10^{-5}$ & $\mathrm{G}\left(\mathrm{CH}_{4}\right) \leq 1 \times 10^{-5}$ \\
\hline & \multicolumn{2}{|}{} \\
$\mathrm{SX}_{\mathbf{i}}$ & 0.217 & 0.190 \\
\hline
\end{tabular}




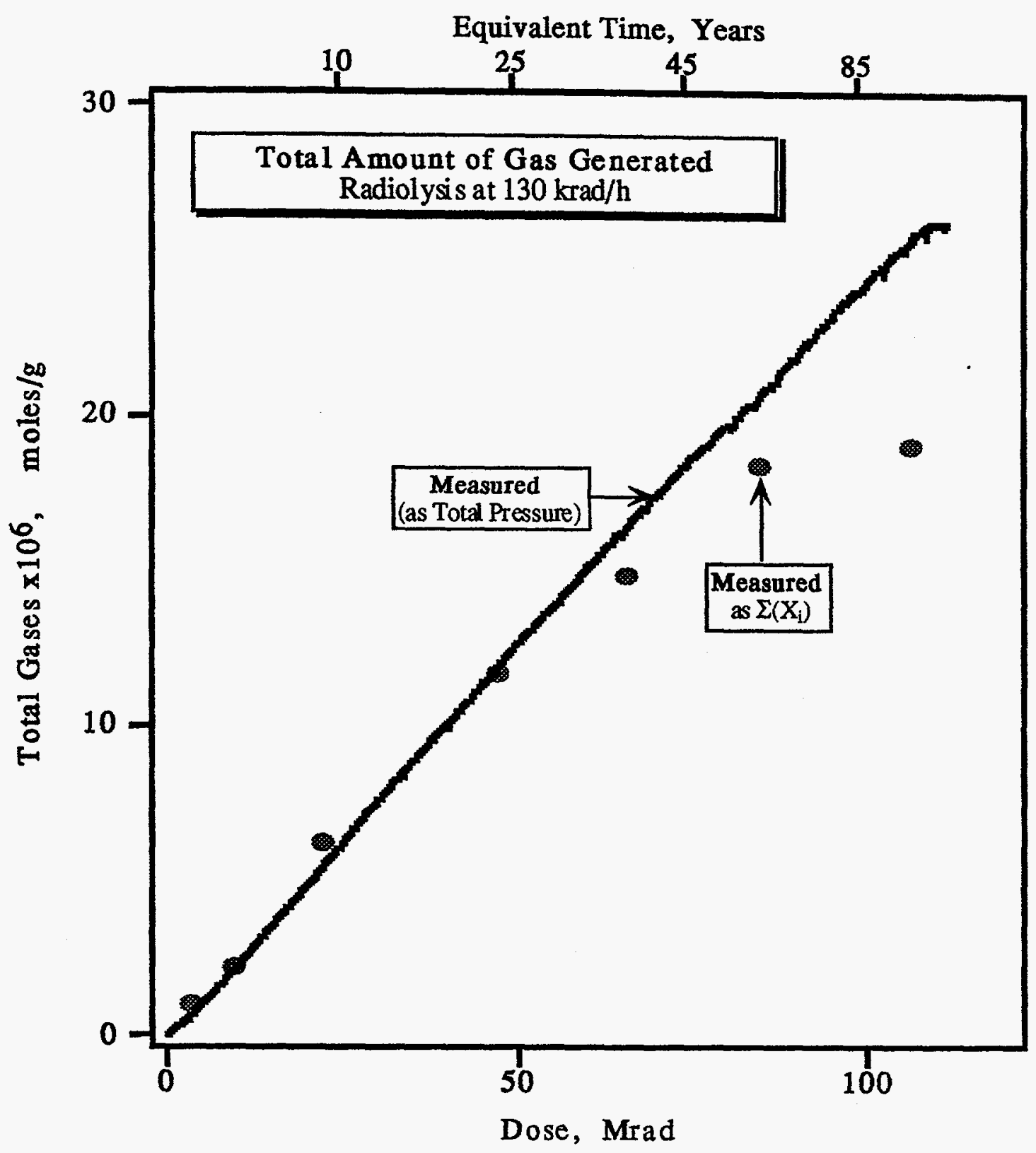

Figure 2. The total amount of gas generated upon irradiation of non-preirradiated grout samples at $130 \mathrm{krad} / \mathrm{h}$. Solid curve shows results from total pressure measurement; Circles are the sum of the individual gases measured by gas chromatography.

\section{DISCLAIMER}

This report was prepared as an account of work sponsored by an agency of the United States Government. Neither the United States Government nor any agency thereof, nor any of their employees, makes any warranty, express or implied, or assumes any legal liability or responsibility for the accuracy, completeness, or usefulness of any information, apparatus, product, or process disclosed, or represents that its use would not infringe privately owned rights. Reference herein to any specific commercial product, process, or service by trade name, trademark, manufacturer, or otherwise does not necessarily constitute or imply its endorsement, recommendation, or favoring by the United States Government or any agency thereof. The views and opinions of authors expressed herein do not necessarily state or reflect those of the United States Government or any agency thereof. 